\section{David Singleton}

Trinity College, Dublin, Ireland

University of Pannonia, Veszprem
(iD) https:/ orcid.org/0000-0003-2720-5965

\title{
Bi-/Multilingual Communication, Identity and the Posited Intermingling of Language Systems in the Mind
}

\begin{abstract}
This article addresses the claim that the notion of bounds between language-varieties in the mind should be abandoned. Such rhetoric has become standard in respect of the conceptual dimensions of language. The proposition does not, however, confine itself to underlying concepts; it calls into question the whole notion that languages in the mind are bounded entities in any of their aspects. The response to this position presented here is that knowledge of languages in the mind is in fact in all its aspects highly differentiated, and that this differentiation broadly follows traditional lines (always recognizing that demarcation between languages is occasionally permeable). Evidence in favour of this view is drawn from a number of areas, including language loss and recovery, bilingual/multilingual development and communication, and the affective dimension of language differentiation.
\end{abstract}

Keywords: bilingual, multilingual, boundedness, differentiation, identity, separate development, interaction, Quintus Ennius, strategic objectives, non-normative

\section{Introduction}

I should like to begin with a story e-mailed to me some years ago by the Finnish psychologist, Elizabet Service, about an experience her multilingual sister had had in France. With her permission I have cited it in a number of publications to illustrate various points, but it seems especially relevant in the current context: 
My sister, while studying in France, was once addressed on the street in Finnish. Only after several attempts by the speaker did she understand her own native language, the point being that she was expecting French.

Service goes on to relate similar episodes in her own life involving her L2, English, a language she speaks to a very high level of proficiency:

I have had a very similar experience trying to make Finnish out of something that was easy enough to understand when I realised it was English.

I shall come back to such experiences, which many of us could probably add to, later. They cast severe doubt, it seems to me, on the proposition of radical intermingling of languages in the mind.

The notion of such radical intermingling is currently very much in the air, this direction of theorizing being encouraged in some people's minds by their interpretation of Dynamic Systems Theory (e.g., De Bot 2008, 2016; De Bot, Lowie, \& Verspoor, 2007). There has been a tendency on the part of many researchers to want to abandon all talk whatever of boundaries or differentiation between languages and language-varieties in the mind. Indeed this is a standard position in respect of the semantic or conceptual dimensions of language (MacKenzie, 2016), where the received wisdom is that for all language-varieties known by the multi-competent user there is a common underlying "conceptual base" (Kecskes \& Papp, 2000) - that is to say equivalence, fusion, and language-neutrality at the conceptual level (see also De Groot, 1992; Costa, 2005; Kroll \& Stewart, 1994).

Athanasoupoulos (2016) has recently addressed this issue, speaking of the need to re-examine the notion of a common conceptual base in respect of the languages of bi-/multilinguals. Citing Pavlenko and Jarvis (Pavlenko, 2005; Jarvis \& Pavlenko, 2008), he points out that most words that are considered "translation-equivalents" across languages do not share the same conceptual representation, even when they denote concrete entities (Ameel et al., 2005), and that there is increasing evidence, from investigations of bilingual cognition, of systematic cross-linguistic variation in the conceptual representation of a range of different domains of experience. His conclusion is that learning a new language involves creating new concepts and recalibrating existing concepts. The desire to dispense with boundaries does not, however, stop at concepts; for some years researchers, of a range of theoretical stances, going well beyond Dynamic Systems Theory, have been tending to call into question the whole notion that languages in the mind in general are bounded entities (e.g., Harris, 1998; Toolan, 2008; Vaid \& Meuter, 2016).

The response to this position adopted here (cf. Singleton 2016, 2018) is that languages in the mind are in all their aspects, in fact, highly differentiated, and 
that such differentiation broadly follows the lines recognized by the traditional boundaries which draw (always, of course, crossable and permeable) lines between languages. The article will make mention of a number of arguments from the evidence of bilingual and multilingual experience which favour the above stance.

\section{Evidence against Unboundedness from Language Loss and Aphasia in Bi-/Multilinguals}

Powerful evidence of separability comes from the phenomenon of the selective recovery of language-varieties known to bi-/multilinguals and lost as a result of brain damage. These patterns of selective recovery do not necessarily relate to distinct neural representations of the different languages, but may have to do with damage to control mechanisms located in the prefrontal cortex that activate the target language and inhibit the non-target language (see, e.g., Abutalebi, 2008), in other words, distinguish between different languages. There is also some mysterious but intriguing evidence from non-parallel aphasia (see, e.g., Fabbro, 1999, Chapters 12-16). In other words, when a bi-/multilingual experiences disruption of his/her language capacity, such disruption does not consistently affect all the languages he/she knows in the same way, as one would expect if language knowledge were an undifferentiated block, but often presents different recovery profiles and different phenomena from language to language.

Whitaker, for example (1978, p. 27), refers to the case of an English scholar in the area of the classical languages and literatures who, after losing all his languages, recovered first Ancient Greek, then Latin, both of which he had encountered as a schoolchild. He subsequently recovered French, which he had learned as an adult, and finally English (his L1). Grosjean, for his part, refers (1982, p. 260) to the instance of a Swiss multilingual who recovered first French (his chronologically third language) and later Standard High German (his chronologically second language), but who never recovered his native variety, Swiss German (which is, of course, very different from Standard German). Fabbro (2002, p. 204) reports the strange case of a person whose first language was Veronese (a variant of Venetian, very different from Standard Italian), who had exclusively used Veronese in all her daily activities, except for a few words of Standard Italian (her second language) very rarely, but who, following a brain injury, started communicating exclusively in Standard Italian. Her condition subsequently improved to the point where she could understand Veronese, but she persisted in her producing only Standard Italian. Another case is that of Jürg Schwyter (Schwyter, 2011), who, following a stroke, lost the use of every one 
of his languages. He recovered receptive capacities in all his languages Swiss German (his chronologically first language), Standard German (his chronologically second language), English, Italian, and French (his later school languages), but has recovered full productive capacities only in his mother tongue, Swiss German, and his main professional language, English. As noted earlier, such selective (and patchy) recovery of languages constitutes an argument the notion that the knowledge and processing of these languages is a unitary phenomenon.

Concerning non-parallel aphasia, Paradis and Goldblum (1989) report the case of a trilingual subject who was a native speaker of Gujarati. The person in question lived in Madagascar, and had additionally acquired Malagasy, Madagascar's official language. At age six he had also learned French at school, and he used this language on a daily basis in his professional activities. Following a neurosurgical operation, he evidenced disorders typifying Broca's aphasia in Gujarati but no deficits in his other languages. Two years after the operation he had fully recovered Gujarati but had difficulties with Malagasy in terms of verbal fluency and syntactic comprehension. Four years after the operation no disorder was detected in either language. (Cf. also Gil \& Goral, 2004). Thus, deep-seated language disorders, which are commonly assumed to affect the totality of languages known to an individual, are shown by such evidence sometimes to be "selective" in terms of the languages they target. Again, such evidence argues for the differentiation and boundedness of languages in the mind.

These cases of selective recovery and non-parallel aphasia are slightly puzzling from an identity perspective, in the sense that, as the above references and discussion indicate, it often seems to be the native language, with which identity would be thought to be strongest, which is longest lost or which is afflicted by disorders. Strong personal identification with a language does not, then, necessarily protect it from the kind of disruption associated with physiological problems affecting the brain. The above evidence certainly does point, however, to the notion that each language in the mind has its own processing dynamic, in other words, has a degree of, as it were, autonomy, of developmental individuality.

\section{Evidence against Unboundedness from Bi-/Multilingual Development and Interaction}

Let us return to the story told by Service showing that it is possible for a person not to understand a language in which he/she is highly proficientincluding his/her mother tongue - if he/she is not expecting to encounter it. 
Another case I was told of very recently by the corpus linguist Sylviane Granger, who was recently in China with her husband, a reasonably proficient learner of Chinese. Often when her husband spoke Chinese, it was not initially reacted to by their Chinese hosts (who also spoke English) - the point being that they were not expecting their L1 from a Westerner. As in the case of the earlierdiscussed instances of language loss due medical reasons, identity with one's L1 or a very strong L2, fails to protect the languages in question - in this case from such occurrences of incomprehension. Such evidence strongly suggests that an L1 or strong L2 - as entire systems - can in certain circumstances be set at a very low level of activation, a radically lower, comprehension-preventing level of activation, than the language(s) one is expecting to encounter. If it is possible for the mind to select a language to render "dormant" in this fashion, as opposed to another language/other languages rendered "ready for action," this clearly implies - speaks volumes about-differentiation of languages in the mind.

Turning to the early developmental front the individuality of the progress of each language is indicated by studies (Schelleter, Sinka, \& Garman, 1997; Sinka \& Schelleter, 1998; Sinka, Garman, \& Schelleter, 2000) which looked at two children acquiring, respectively, Latvian and English and German and English. Latvian and German are both highly inflected languages, whereas English is, of course, not. The researchers found evidence of the development of functional categories in Latvian and German from the earliest stages, but not in English, from which the researchers conclude that the nature of Latvian and German input is rich enough to trigger early functional category development, whereas the English input is not. The faster development of functional categories in these cases seemed to have nothing to do with identification with the languages in question and everything to do with the nature of what the children were exposed to. The strong implication of these findings is, however, again that, whatever about identity, the languages acquired by a simultaneous bi-/ multilingual develop separately. The question of whether this is in fact the case from the very earliest stages of acquisition has been quite a controversial one.

One much-cited view is that the simultaneous bi-/multilingual begins with a single language system and that his/her languages separate only at a later stage (e.g., Volterra \& Taeschner, 1978; see discussion in Clark, 2016, pp. 386ff.). This hypothesis suggests that simultaneous bi-/multilinguals begin with a single language system, a single fused linguistic representation, and that it is only around the age of three years that they begin to differentiate their languages (see, e.g., Pettito et al., 2001, p. 455). According to this view, the child at the very early stages of language development is not in possession of translation-equivalents across languages, but rather he or she has a single lexical store, with a single word from one or other of his/her languages for any given meaning. On this basis, the evidence cited in favour of the above perspective tended to be that 
of language mixing (cf. Macrory, 2006: 163; cf. Nicoladis \& Genesee, 1997). The claim was that mixed utterances arose because the child at an early stage did not have access to translation-equivalents across languages, that he or she had just one lexical store, with a particular word from one or other of his/her languages for any given meaning.

It is irrefutable that language mixing goes on in the language use of young multilinguals, and that much of this mixing happens because a child may know an expression in one language for which he/she has no equivalent in other languages. Nicoladis and Secco (2000), for example, report that around 90\% of the mixing they observed in very young bilinguals was explicable in terms of lexical gaps in one language or the other. That is to say, when the children lacked the expression they needed in one language but had it at their disposal in their other language, they simply drew on what they knew to supplement what they did not know. This strategy undoubtedly continues throughout childhood and indeed into adulthood simply because languages differ in their conceptual patterning and learners of every age have less than complete mastery of such patterning (cf. Gessman, 2014). Zhang (2006) demonstrates this with respect to siblingsibling interaction between two Chinese-English bilingual children, where, for instance, the Chinese expressions kao-ya ('roast duck') and fu-lu ('pickle made from soya beans') were used in English matrix utterances because the English translation-equivalents were unknown (and in the latter case non-existent).

This is a very natural strategy for the multilingual child to adopt. It of itself says nothing about the question of the separation or integration of a young multilingual's languages. Quay (1995), for her part, shows the falsity of the notion that the multilingual's lexicon is systematically distributed across languages; and she, accordingly, strongly disputes the claim that there is a stage at which the multilingual has just one item in one or other language for a particular meaning (cf. also Deuchar \& Quay, 2000). Bi-/multilingual children, in other words, generally keep their languages apart when using them, and they are highly adept — even at a very early age (see, e.g., Genesee, Nicoladis, \& Paradis, 1995; Nicoladis, 1998)--at making decisions as to which language to speak to whom. It seems, moreover, that on occasions where languages are mixed, the mixing in question may evidence an awareness - again from an early age - of the language competencies of interlocutors (see, e.g., Lanza, 1997).

De Houwer puts it this way:

Like monolingual children, bilingual children pay a lot of attention to the input they receive. They soon notice that this input differs depending on who is talking and in what situation someone is talking. Just like monolingual children, bilingual children attempt to talk like the people around them. Because of the bilingual situation, however, the bilingual child has 
more options than the monolingual one ... [A]t a very young age bilingual children are skilled conversationalists who easily switch languages.

(De Houwer, 1995, p. 248: cf. Chevalier, 2015, for some interesting insights into trilingual children's interaction)

\section{The Affective Dimension and Quintus Ennius's Three Hearts}

In their normal functioning adult bi-/multilinguals too, of course, are very attentive in their use or non-use of specific languages to the linguistic identities and competencies of their interlocutors. This is clearly a necessary condition of successful communication. The bounds of a language in the bi-/multilingual's mind are thus clearly set by, if by nothing else, the linguistic identities of others, and by the consequent limits of intelligibility. Especially interesting in this connection is the case of interlingual couples and families (see, e.g., Singleton \& Pfenninger, 2018). Often two people who get involved romantically with each other and who speak different languages opt for one they identify as their "language of the heart" (Dewaele \& Salomidou, 2016). This language is then set apart from other languages in their repertoire by strong, affective factors. Piller found that many couples perceive their private language as the foundation of their relationship: "[...] we were both happy then that we could speak German, and our relationship started with drinking coffee and speaking, and so speaking was very important to us and whenever we are having a serious conversation, it really needs to be in German, otherwise it doesn't go well, and it doesn't feel right" (Piller, 2002, p. 222). Usually the language in question is the L1 of one of the couple, but not always.

In this context, I should like to refer to the interesting case of a couple I came across quite recently. The couple, named for present purposes Solange and Jan, met in France where Solange grew up; Jan is Dutch. They have used English with each other from the start of their relationship. They are now married and living in the Netherlands and they both now have a good command of each other's language but they continue to identify English as their "language of the heart" for their private conversations. They have a three year-old daughter with whom Solange communicates in French and Jan in Dutch. The common language of the household is sometimes Dutch and sometimes French. The daughter does not yet know English and makes fun of her parents when she hears them speak their language of intimacy.

The differentiation of the use of the languages is thus clear:

Solange to daughter: French

Jan to daughter: Dutch

Solange to Jan to Solange (family matters): French/Dutch

Solange to Jan to Solange (couple matters): English 
This is anything but a mish-mash. The bounds in the language users' minds are in this case set by, among other factors, the role of English as the couple's language of intimacy. The intelligibility factor also comes into the picture, though, in the sense that everyone in the trio understands French and Dutch, and in the sense that English is (for the parents happily) unintelligible to the daughter. (This latter situation will no doubt change with time and circumstances-especially when the child reaches school age).

This talk of intimacy leads inevitably to Quintus Ennius's much-discussed three hearts. Quintus Ennius, who flourished in the second and third centuries B.C., has been called the "father of Latin poetry." He was a prolific writer, but his works in the centuries after the early Roman emperors fell into disfavour, with the result that only fragments of his opus survive. His principal claim to fame is his remark (reported by the later author Aulus Gellius) that because he knew three languages (Latin, Greek, and Oscan) he had three hearts: "Quintus Ennius tria cordia habere sese dicebat, quod loqui Graece et Osce et Latine sciret."

It should be noted that the word for heart in Latin-cor-was applied to the seat of intelligence as well as the seat of the emotion. Part of what Quintus Ennius was saying, then, coincided with the truism of twentieth century linguistics (see Lyons, 1963, pp. 37ff.), according to which every language articulates the world uniquely in terms of its various structures and consequently in terms of its concepts and configurations of concepts, a truism which is not lightly to be discarded (see, e.g., earlier discussion of Athanasoupoulos, 2016). Its implication is that, in order to function intelligibly and comprehendingly in the relevant language communities, users of multiple languages need to make use of structural and conceptual systems specific to each of their languages, systems which are of their nature differentiated from those of their other languages. The reality of a degree of cross-linguistic permeability, influence and interaction, which has been recognized since the dawn of time, does not imply an undermining of the other reality of essential differentiation between language systems in the mind (cf. Singleton 2003, 2012).

Quintus Ennius was also undoubtedly talking, however, about the affective dimension of his three hearts, and this dimension is certainly a feature of modern research into the management of multiple languages. In emotion research (e.g., Keysar, Hayakawa, \& An, 2012; Pavlenko, 2012) it has been suggested that words that label emotion are typically represented at a deeper level of conceptual understanding in a native or dominant language as compared to their second language representation. Also, Dewaele (2016) discusses Pavlenko's (2006) account of the feedback that emerged from the (Dewaele \& Pavlenko, 2001-2003) Bilingualism and Emotion Questionnaire, where her findings was that almost two-thirds of participants reported feeling like different people when they switched languages - a phenomenon with which many 
readers of the present text-as well as its writer-will identify. The evidence from the emotional level too, then, clearly favours differentiation between the multilingual's languages.

\section{A European Phenomenon?}

The (distinctly racist) occasional riposte that I have (recently) encountered to all of the above is that differentiation may indeed be a feature of language management in European contexts but that all over Africa and Asia "mishmash" is the norm. The idea seems to be that separating languages is a function of naming them, of standardizing them, of reading and writing them-as if these phenomena were, in any case, confined to European contexts.

I want to take just two examples to begin to "nail" this myth. The first is from Canagarajah's (2009) study of a job interview in Sri Lanka. The following quote is from the candidate for the position in question-mixing Tamil and English. This looks like "mish-mash" if ever there was such!

Naan sociology of religion - ilai taan interested. Entai thesis topic vantu

'the rise of local deities in the Jaffna peninsula' ... Oom, oru ethnographic study — aai taan itay ceitanaan. kittattatta four years — aai field work ceitanaan.

It is in the sociology of religion that I am interested. My thesis topic was 'the rise of local deities in the Jaffna peninsula'... Yes, I did this as an ethnographic study — I did field work for roughly four years.

Canagarajah's commentary, however, is that the candidate makes full use of his receptive multilingualism and of the English scholarly expressions at his disposal in coping with the interviewer's questions, and strategically draws on the English at his command to shift the interaction in his favour. What might have appeared at first sight to be a chaotic throwing together of Tamil and English is in fact a delicately patterned exploitation of the two languages, taking account of differences in their status and function - shot through with the different strategic objectives attached to the use of each of the two languages. No confusion here, then, but skilfully exploited differentiation at every turn of the way.

My second example is from Yager and Gullberg's (2019) account of semantic non-convergence in the competencies of Jedek-Jahai bilinguals in northern Peninsular Malaysia. Jedek and Jahai are lexically and typologically similar languages, and, therefore, on the basis of all the work on psychotypologicallyrelated cross-linguistic influence, one would expect cross-linguistic interaction between them in Jedek-Jahai bilinguals. And indeed such there is, but-in this non-normative, non-standardized, non-literate setting, there is surprisingly little semantic convergence. To quote the authors: "Contrary to predictions, the results 
did not reveal a general increase in the congruence of Jedek and Jahai extensions in the bilingual groups. Instead, there was an increase in incongruence only where there was also form overlap in the two languages." Obviously more work needs to be done on cross-linguistic interaction in such environments, but the notion that non-normative settings promote the wholesale blending of languages, is in the light of the above very dubious.

\section{Envoi}

To sum up, evidence from all of the areas discussed above point firmly in the direction of the differentiation of languages in the bi-/multilingual mind. Differential language loss and recovery as well as language disorders following stroke or brain surgery indicate that internalized language systems each have their own dynamic. The same conclusion is favoured by various aspects of normal bi-/multilingual development; in particular, the fact that different dimensions of language develop at different speeds in the bi-/multilingual's languages, the refutation of the claim that there is a stage at which the bi-/ multilingual child has just one item in one or other language for a particular meaning/function and the evidence that bi-/multilingual children are adept from a very early age at deciding which language needs to be spoken to whom. The differentiation of the bi-/multilingual's languages is also apparent in the different affective roles they can have in family life and in the different ways people seem often to feel when using them. An important footnote on the above is that bi-/multilingual language use is no more characterized by "mish-mash" in places like Sri Lanka and Malaysia than it is in European settings.

An illuminating sidelight is cast on this matter by Werker's discussion of infant speech perception. Werker points out that the infant engaged in the process of language development has to deploy his/her perceptual knowledge of "the rhythmical properties of the [...] language, of the speech sound categories that distinguish one possible word from another, and of the sequences of sounds that are allowable within a word and/or the statistical learning of other cues to segmentation" (Werker, 2012, p. 50). Only in so doing, she says, can the child isolate different words and structures and map them on to meaning. The child who grows up in an environment involving more than one language, she goes on to point out, has to master the rhythmical properties, the phonetic categories, the phonotactic regularities, the word order patterns, the lexis-concept configuration and the conceptualisation of the world of each language. What is more, the infant bilingual must do this, she states, without interlingual confusion.

The obvious comment to add, of course, is that what applies to the child multilingual applies to multilinguals of any and every age. 


\section{Note}

I should like to acknowledge with thanks some very useful comments that Simone Pfenninger made on an earlier version of this text.

\section{References}

Abutalebi, J. (2008). Neural aspects of second language representation and language control. Acta Psychologica, 128, 466-478.

Ameel, E., Storms, G., Malt, B., \& Sloman, S. (2005). How bilinguals solve the naming problem. Journal of Memory and Language, 53(1), 60-80.

Athanasoupoulos, P. (2016). Cognitive consequences of multi-competence. In V. Cook \& Li Wei (Eds.), The Cambridge handbook of linguistic multi-competence (pp. 355-375). Cambridge: Cambridge University Press.

Canagarajah, S. (2008). The plurilingual tradition and the English language in South Asia. AILA Review, 12, 5-22.

Chevalier, S. (2015). Trilingual language acquisition: Contextual factors influencing active trilingualism in early childhood. Amsterdam: John Benjamins.

Clark, E. V. (2016). First language acquisition. 3rd Edition. Cambridge: Cambridge University Press.

Costa, A. (2005). Lexical access in bilingual production. In J. F. Kroll \& A. M. B. de Groot (Eds.), Handbook of bilingualism: Psycholinguistic approaches (pp. 308-325). New York: Oxford University Press.

De Bot, K. (2008). Introduction. Second language development as a dynamic process. The Modern Language Journal, 92(2), 166-178.

De Bot, K. (2016). Multi-competence and dynamic/complex systems. In V. Cook \& Li Wei (Eds.), The Cambridge handbook of linguistic multi-competence (pp. 125-141). Cambridge: Cambridge University Press.

De Bot, K., Lowie, W., \& Verspoor, M. (2007). A Dynamic Systems Theory approach to second language acquisition. Bilingualism: Language and cognition, 10(1), 7-21.

De Groot, A. M. B. (1992). Bilingual lexical representation: A closer look at conceptual representations. In R. Frost \& L. Katz (Eds.), Orthography, phonology, morphology and meaning (pp. 389-412). Amsterdam: North Holland.

De Houwer, A. (1995). Bilingual language acquisition. In P. Fletcher \& B. MacWhinney (Eds.), The handbook of child language (pp. 219-250). Malden, MA: Blackwell.

Deuchar, M., \& Quay, S. (2000). Bilingual acquisition: Theoretical implications of a case study. Oxford: Oxford University Press.

Dewaele, J.-M. (2016). Multi-competence and emotion. In V. Cook \& Li Wei (Eds.), The Cambridge handbook of linguistic multi-competence (pp. 461-477). Cambridge: Cambridge University Press.

Dewaele, J.-M., \& Salomidou, L. (2017). Loving a partner in a foreign language. Journal of Pragmatics, 108, 116-130.

Dewaele, J.-M., \& Pavlenko, A. (2001-2003). Web questionnaire: Bilingualism and emotions. University of London. 
Fabbro, F. (1999). The neurolinguistics of bilingualism: An introduction. Hove: Psychology Press.

Fabbro, F. (2002). The neurolinguistics of L2 users. In V. Cook (Ed.), Portraits of the L2 user (pp. 167-195). Clevedon: Multilingual Matters.

Genesee, F., Nicoladis, E., \& Paradis, J. (1995). Language differentiation in early bilingual development. Journal of Child Language Development 22(3), 611-631.

Gessman, A. M. (2014). Another language--Another pattern of thinking. CLA Journal, 57(4), 269-278.

Gil, M., \& Goral, M. (2004). Non-parallel recovery in bilingual aphasia: Effects of language choice, language proficiency and treatment. International Journal of Multilingualism, 8(2), 191-221.

Grosjean, F. (1982). Life with two languages: An introduction to bilingualism. Cambridge, MA: Harvard University Press.

Harris, R. (1998). An introduction to integrational linguistics. Kidlington: Elsevier.

Jarvis, S., \& Pavlenko, A. (2008). Crosslinguistic influence in language and cognition. New York: Routledge.

Keysar, B., Hayakawa, S. L., \& An, A. G. (2012). The foreign-language effect: Thinking in a foreign tongue reduces decision biases. Psychological Science, 23(6), 661-668.

Kroll, J. F., \& Stewart, E. (1994). Category interference in translation and picture naming: Evidence for asymmetric connections between bilingual memory representations. Journal of Memory and Language, 33(2), 149-174.

Lanza, E. (1997). Language mixing in infant bilingualism: A sociolinguistic perspective. Oxford: Clarendon Press.

Lyons, J. (1963). Structural semantics: An analysis of part of the vocabulary of Plato. Volume 20 of Publications of the Philological Society. Oxford: Blackwell.

MacKenzie I. (2016). Multi-competence and English as a lingua franca. In V. Cook \& Li Wei (Eds.), The Cambridge handbook of linguistic multi-competence (pp. 478-501). Cambridge: Cambridge University Press.

Macrory, G. (2006). Bilingual language development: What do early years practitioners need to know? Early Years, 26(2), 159-169.

Nicoladis, E. (1998). First clues to the existence of two input languages: Pragmatic and lexical differentiation in a bilingual child. Bilingualism: Language and Cognition, 1(2), 105-116.

Nicoladis, E., \& Genesee, F. (1997). Language development in preschool bilingual children. Journal of Speech. Language Pathology and Audiology, 21(4), 258-270.

Nicoladis, E., \& Secco, G. (2000). The role of a child's productive vocabulary in the language choice of a bilingual family. First Language, 58(1), 3-28.

Paradis, M., \& Goldblum, M. C. (1989). Selective crossed aphasia in a trilingual aphasic patient followed by reciprocal antagonism. Brain and Language, 36, 62-75.

Pavlenko, A. (2005). Bilingualism and thought. In J. F. Kroll \& A. M. B. de Groot (Eds.), Handbook of bilingualism. Psycholinguistic approaches (pp. 433-453). Oxford, UK: Oxford University Press.

Pavlenko, A. (2012). Affective processing in bilingual speakers: Disembodied cognition? International Journal of Psychology, 47(6), 405-428.

Piller, I. (2002). Bilingual couples talk: The discursive construction of hybridity. Amsterdam: John Benjamins.

Pettito, L. A., Katerelos, M., Bronna, G., Levy, K. G., Tétreault, K., \& Ferraro, V. (2001). Bilingual signed and spoken language acquisition from birth: Implications for the mechanisms underlying early bilingual language acquisition. Journal of Child Language Acquisition, 28(2), 453-496.

Quay, S. (1995). The bilingual lexicon: Implications for studies of language choice. Journal of Child Language 22(2), 369-387. 
Schelleter, C., Sinka, I., \& Garman, M. (1997). Latvian/English and German/ English bilingual acquisition: New light on Universal Grammar. In Proceedings of the First International Symposium on Bilingualism (pp. 442-452). Vigo: University of Vigo.

Schwyter, J. R. (2011). "Me talk funny": A stroke patient's personal account. English Today, $27(4), 49-52$.

Singleton, D. (2003). Perspectives on the multilingual lexicon: A critical synthesis. In J. Cenoz, B. Hufeisen, \& U. Jessner (Eds.), The multilingual lexicon (pp. 167-176). Amsterdam: Kluwer Academic.

Singleton, D. (2012). Multilingual lexical operations: Keeping it all together ... and apart. In J. Cabrelli Amaro, S. Flynn, \& J. Rothman (Eds.), Third language acquisition in adulthood (pp. 95-114). Amsterdam: John Benjamins.

Singleton, D. (2016). A critical reaction from second language acquisition research. In V. Cook \& Li Wei (Eds.), The Cambridge handbook of linguistic multi-competence (pp. 502-520). Cambridge: Cambridge University Press.

Singleton, D. (2018). Multilingualism, multi-competence and (limits to) the interaction between language systems. Teanga: The Irish Journal of Applied Linguistics, 25, 1-14.

Singleton, D., \& Pfenninger, S. E. (2018). L2 Proficiency as a function of cultural identity in interlingual couples. Theory and Practice of Second Language Acquisition, 4(1), 7-22.

Sinka, I., Garman, M., \& Schelleter, C. (2000). Early verbs in bilingual acquisition. Reading Working Papers in Linguistics, 4, 175-187.

Sinka, I., \& Schelleter, C. (1998). Morphosyntactic development in bilingual children. Journal of Bilingualism 2(3), 301-326.

Toolan, M. (2008). Introduction: Language teaching and integrational linguistics. In M. Toolan (Ed.), Language teaching: Integrational linguistic approaches (pp. 1-23). London: Routledge.

Vaid, J., \& Meuter, R. (2016). Not through a glass darkly: Refocusing the psycholinguistic study of bilingualism through a 'bivocal' lens. In V. Cook \& Li Wei (Eds.), The Cambridge handbook of linguistic multi-competence (pp. 77-96). Cambridge: Cambridge University Press.

Volterra, V., \& Taeschner, T. (1978). The acquisition and development of language by bilingual children. Journal of Child Language, 5(2), 311-326.

Werker, J. F. (2012). Perceptual foundations of bilingual acquisition in infancy. Annals of the New York Academy of Sciences, 1251, 50-61.

Whitaker, H. (1978). Bilingualism: A neurolinguistics perspective. In W. Ritchie (Ed.), Second language acquisition research: Issues and implications (pp. 21-32). New York: Academic Press.

Werker, J. F. (2012). Perceptual foundations of bilingual acquisition in infancy. Annals of the New York Academy of Sciences, 1251, 50-61.

Yager, J., \& Gullberg, M. (2019). Asymmetric semantic interaction in Jedek-Jahai bilinguals: Spatial language in a small-scale, non-standardized, egalitarian. long-term multilingual setting in Malaysia. International Journal of Bilingualism, https://doi.org/10.1177/1367006918814378

Zhang, H.-Q. (2006). Bilingual sibling interaction: A case study of linguistic features and their social functions. MPhil dissertation. Trinity College Dublin. 
David Singleton

\title{
Kommunikation zwei-/mehrsprachiger Personen, Identität und vermeintliche Durchdringung von Sprachsystemen im Kopf
}

\begin{abstract}
Zusammenfassung
Der Beitrag setzt sich mit der Behauptung auseinander, dass das Konzept der Grenzen zwischen sprachlichen Variationen im Kopf aufgegeben werden sollte. Eine solche Rhetorik wurde zu einem Standard in Bezug auf die konzeptuellen Aspekte der Sprache. Diese Behauptung ist jedoch nicht auf die Grundbegriffe beschränkt; sie stellt das Konzept in Frage, dass Sprachen im Kopf ganzheitliche Systeme sind, die in jeder Hinsicht voneinander getrennt sind. Als Reaktion auf die Diskussion wird in diesem Beitrag die Auffassung vertreten, dass das Wissen über die im Kopf gespeicherten Sprachen tatsächlich sehr unterschiedlich ist und dass diese Differenzierung im Prinzip traditionellen Grundsätzen entspricht (wobei stets anerkannt wird, dass die Grenzen, die die Sprachen voneinander trennen, manchmal durchlässig sind). Die für diese Sichtweise sprechenden Beweise kommen aus vielen Bereichen, einschließlich des Sprachverlustes und der Sprachwiederherstellung, der Entwicklung und Kommunikation von zwei-/mehrsprachigen Personen und der affektiven Dimension der Sprachenvielfalt.
\end{abstract}

Schlüsselwörter: zweisprachige Person, mehrsprachige Person, Einschränkung, Vielfalt, Identität, eigenständige Entwicklung, Interaktion, Quintus Ennius, strategische Ziele, mangelnde Normativität 